University for Business and Technology in Kosovo

UBT Knowledge Center

UBT International Conference

2016 UBT International Conference

Oct 28th, 9:00 AM - Oct 30th, 5:00 PM

\title{
UNESCO World Heritage and Kosovo Towards a Tentative List for Kosovo
}

Caroline Jaeger Klein

Vienna University of Technology, jaeger-klein@tuwien.ac.at

Follow this and additional works at: https://knowledgecenter.ubt-uni.net/conference

Part of the Architecture Commons

\section{Recommended Citation}

Klein, Caroline Jaeger, "UNESCO World Heritage and Kosovo Towards a Tentative List for Kosovo" (2016). UBT International Conference. 65.

https://knowledgecenter.ubt-uni.net/conference/2016/all-events/65

This Event is brought to you for free and open access by the Publication and Journals at UBT Knowledge Center. It has been accepted for inclusion in UBT International Conference by an authorized administrator of UBT Knowledge Center. For more information, please contact knowledge.center@ubt-uni.net. 
Book of Proceedings

International Conference on Architecture and Spatial Planning

\title{
UNESCO World Heritage and Kosovo Towards a Tentative List for Kosovo.
}

\author{
Caroline Jaeger-Klein \\ Vienna University of Technology, Department for History of Architecture and Building \\ Archaeology, Karlsplatz 13/251; A-1040 Vienna, Austria \\ jaeger-klein@tuwien.ac.at
}

\begin{abstract}
In 2015, Kosovo tried to join UNESCO and failed by three quotes. Is Kosovo ready for its UNESCO membership? At least for its national architectural heritage, this question is to answer with no. The intensively discussed issue of the medieval monuments of Kosovo inscribed as UNESCO World Heritage by Serbia and Montenegro before the declaration of independency in 2008 and their further management through Kosovo is just one aspect. More troubling is that the rather young state not yet could establish sufficient structures to gain a systematic inventory of its monuments, sites and historic ensembles, nor to extract a tentative list for UNESCO out of such an encompassing inventory. This article intends to clarify the definitions of World Heritage, the institutions and NGO's involved, the mechanisms and philosophies behind. What is the urgent homework for Kosovo? Which national and international groups of experts Kosovo has to name and make responsible for the systemic inventory of its architectural heritage and for creating a tentative list? What is the role and importance of ICOMOS in that process? Which other stakeholders have to be Identified and educated towards that issue?

Based on such general considerations the author tries to design finally a preliminary tentative list for the architectural heritage of Kosovo. Hence, not the list itself is of importance but the discussion of the pro and contra arguments for single candidates.
\end{abstract}

Keywords: Architectural Heritage, Kosovo, UNESCO, ICOMOS, World Heritage List, World Heritage Center, Tentative List, Heritage in Danger, Heritage at Risk, Documentation and Inventory.

\section{Introduction}

The United Nations Educational, Scientific and Cultural Organization (UNESCO) is a specialized agency of the United Nations (UN). Its purpose is to contribute to peace and security by promoting international collaboration through educational, scientific, and cultural reforms in order to increase universal respect for justice, the rule of law, and human rights along with fundamental freedom proclaimed in the United Nations Charter It is the heir of the League of Nations' International Committee on Intellectual Cooperation. UNESCO pursues its objectives through five major programs: education, natural sciences, social/human sciences, culture and communication/information. Projects sponsored by UNESCO include literacy, technical, and teacher-training programs, international science programs, the promotion of independent media and freedom of the press, regional and cultural history 
projects, the promotion of cultural diversity, translations of world literature, international cooperation agreements to secure the world cultural and natural heritage (World Heritage Sites) and to preserve human rights, and attempts to bridge the worldwide digital divide. It is also a member of the United Nations Development Group. ... UNESCO's aim is "to contribute to the building of peace, the eradication of poverty, sustainable development and intercultural dialogue through education, the sciences, culture, communication and information". Other priorities of the organization include attaining quality Education For All and lifelong learning, addressing emerging social and ethical challenges, fostering cultural diversity, a culture of peace and building inclusive knowledge societies through information and communication. [1]

In fact, nowadays the most prominent issue of UNESCO is its World Heritage List, encompassing sites and landscapes of the cultural and natural heritage of the world, which should be preserved for the future generations as common heritage. Therefore, architecture as scientific discipline, in particular the field of architectural history, plays a major role in this matter. Already UNESCO's headquarters buildings in Paris, inaugurated in 1958, served as role model for peaceful international cooperation on example of architecture. The plans for the three headquarters buildings were prepared jointly by Marcel Breuer of the United States, Pier Luigi Nervi of Italy and Bernard Zehrfuss of France. They were approved by an international panel of five architects: Lucio Costa (Brazil), Walter Gropius (United States), Charles Le Corbusier (France), Sven Markelius (Sweden) and Ernesto Rogers (Italy). American architect Eero Saarinen was also consulted. The result, - a distinctive Y-shaped design on seventy-two columns of concrete piling - is an icon of the international modern style shortly after World War II.

As Kosovo in 2015 tried to join UNESCO, and probably will try it again in 2017, this article tries to frame all implications and responsibilities that will come up for the rather young state with its architectural heritage being than part of the world's common built heritage. How are the mechanisms of listing, for example, working?

What has to be prepared, and who has to prepare? Which technical assistance by experts is necessary? Which strategies did develop recently on the issue? And finally, which charts and guidelines do exist? Well, the last question should be answered already here as introduction. All is based on the World Heritage Convention from 1972. Issues related to it are coordinated through the World Heritage Centre (WHC): the doctrinal texts, the guidelines, the nomination process and it's preparation by the state parties, the lists and a global strategy for listing, the monitoring of the listed heritage and finally, the warning and de-listing, if necessary. In general, all material related on the issue, is public (via internet: UNESCO/world heritage or ICOMOS), visible for everybody and published in the major languages of the world, but we recommend being well prepared on its specific termination. Additionally, quite interesting and in big discussion for the moment, are certain processes of political lobbying behind the mere technical reports. Therefore we recommend various critical articles published recently by and around Lynn Meskell from Stanford University like UNESCO's World Heritage Convention at 40: Challenging the Economic and Political Order of International Heritage Conservation (August 2013, Current Anthropology), States of Conservation: Protection, Politics, and Pacting within UNESCO's World Heritage Committee (January 2014, Anthropological Quarterly), Multilateralism and UNESCO World Heritage: Decision-making, States Parties and political process (May 2015, International Journal of Heritage Studies, L. Meskell et al.), Shifting the balance of power in the UNESCO World Heritage Committee: an empirical assessment (June

2015, International Journal of Cultural Policy, E. Bertacchini et al.), World Heritage Regionalism: UNESCO from Europe to Asia (November 2015, International Journal of Cultural Property, L. Meskell at al.)

\section{UNESCO World Heritage and Kosovo}


Book of Proceedings

International Conference on Architecture and Spatial Planning

\subsection{UNESCO World Heritage in general}

Also for the concentrated description of UNESCO and World Heritage, there is hardly any better than the one by Lynn Meskell to be found: In 1945, the United Nations Educational, Scientific and Cultural Organisation (UNESCO) was created with a constitution mandating "the conservation and protection of the world's inheritance of books, works of art and monuments of history and science". Soon after, this commitment was transformed into proactive international assistance: the first mission was launched in 1959 for the Nubian monuments of Egypt, which were threatened by the construction of the Aswan Dam. In 1965, the idea of a World Heritage Trust was first proposed during the White House Conference in the US and the term "world heritage" was coined. In 1972, the General Conference of UNESCO adopted The Convention Concerning the Protection of the World Cultural and Natural Heritage. It established a new provision for the international and collective protection of heritage with "outstanding universal value" (OUV). The Convention created a set of obligations to protect the past for future generations, an aspiration for a shared sense of belonging and a global solidarity [2]. The Conventions defines the cultural and natural heritage, its national and international protection through the signatory states, the constitution of the intergovernmental committee for the protection of the cultural and natural heritage (World Heritage Committee), the establishment of a fund to protect (World Heritage Fund) and conditions and arrangements for international assistance, the educational programs as well as the reporting.

In 1992, UNESCO established the WHC to act as the Secretariat and coordinator within UNESCO for all matters related to the Convention. The Centre is located in Paris and for the moment directed by the German Mechtild Rössler. The World Heritage Committee within UNESCO is the executive committee to decide annually about the listing of cultural and natural sites in the World Heritage List. If the condition of a particular world heritage is no longer according to its criteria, UNESCO deletes the monument, site or cultural landscape from its World Heritage List after various warnings from the WHC ("Heritage Alert"). The most prominent case within Europe is Dresden Elbe Valley, which fell from the list due to the building of a four-lane bridge ("Waldschlösschenbrücke") in the heart of the cultural landscape in 2009. Nearly the same happened in Cologne when a spectacular museums' project in the neighborhood of the dome won the international architectural competition. In that case, the city authorities chose to modify the architectural project under the guidelines of the ICOMOS expertise and so Cologne did not lose its status as world heritage site.
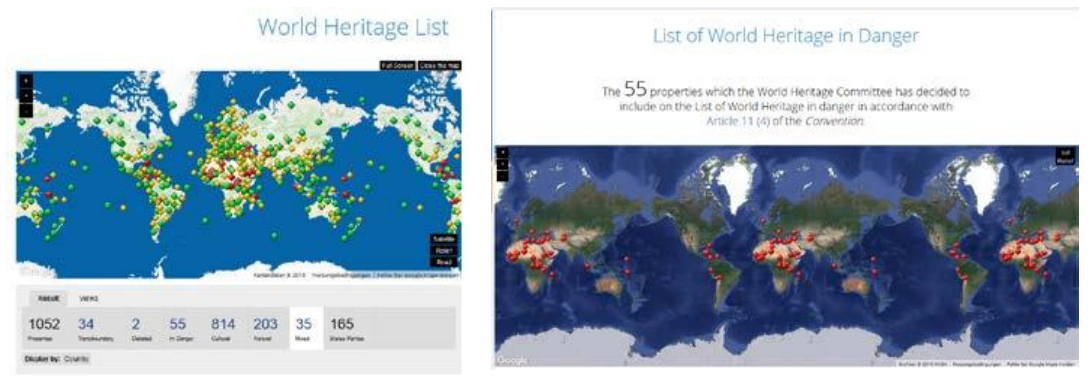

Fig. 1. The World Heritage List of UNESCO, left, and List of World Heritage in Danger with Medieval Monuments in Kosovo, right (screenshots: www.unesco.org/culture/World Heritage Centre/The List) 


\subsection{The Process of Listing}

The WHC organizes annual sessions of the World Heritage Committee. The Committee consists of 21 State Parties, elected at a General Assembly, that serve a four-year term. State Parties are the signatories to the Convention. The Committee's mandate is to develop policies and overarching framework for the implementation of the Convention, to decide on new nominations to the World Heritage List, oversee monitoring and managing of sites already on that List and consider the need for special measures regarding World Heritage in Danger. [2]

The WHC provides advice to State Parties in the preparation of site nominations, but the listing is the business of the National State itself, according to specific guidelines (Operational Guidelines). Over the times, (private) offices specialized on writing those elaborate nomination dossiers for the states. Advisory Bodies of UNESCO evaluate these dossiers before they go into the annual sessions of the World Heritage Committee. The WHC along with the Advisory Bodies also organizes international assistance from the World Heritage Fund and coordinates both the reporting on the condition of sites (Periodic Reporting, Reactive and Preventive Monitoring) and the emergency action undertaken, when the site is threatened. The Advisory Bodies are comprised of International Experts who conduct monitoring missions and evaluations: The International Centre for the Study of Preservation and Restoration of Cultural Property (ICCROM), the International Council on Monuments and Sites (ICOMOS) and the International Union for Conservation of Nature (IUCN).

For architects ICOMOS is the adequate Advisory Body to engage in. ICOMOS experts from signatory states of UNESCO are organized in so-called National Committees (NC). If the state is not (yet) State Party like Kosovo, its experts still can become international ICOMOS members. With the UNESCO membership of the national state its experts listed in Paris by nationality will automatically form a NC with full voting mandate in the General Assembly. Therefore, the participants of the group meeting of the ICOMOS NCs of the South East European Region in Vienna 2013 welcomed already the author's efforts to form an ICOMOS group Kosovo.
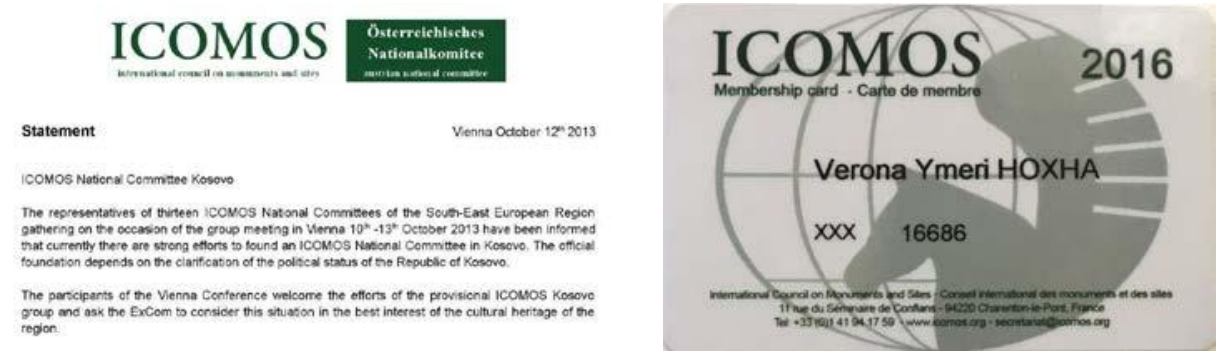

Fig. 2. ICOMOS South East European Region Meeting 2013: Welcome statement to form an ICOMOS group Kosovo; right: ICOMOS Membership card of an international expert from Kosovo, listed as International Expert (xxx) without National Committee behind.

Especially for UNESCO world heritage nominations of a state, a National Committee plays an important role. There are varying degrees of involvement of the National Committees in the process of compiling the Tentative List and in selecting sites to be nominated for inscription in the World Heritage List. National Committees are encouraged to contribute to the selection of sites for inclusion in Tentative Lists or preparation of nominations for inscription. National Committees are encouraged to respond to requests from the ICOMOS World Heritage Unit for opinion on nominations, and that such opinions are confidential between ICOMOS and the National Committees. A dialogue should 
be established between the ICOMOS World Heritage Unit and National Committees over the identification of appropriate experts to undertake missions or to write desk reviews for evaluation. [3] For special matters, ICOMOS additionally is consulting The International Committee for the Conservation of the Industrial Heritage (TICCIH), the International Federation of Landscape Architects (IFLA) and the International Working Party for Document and Conservation of Buildings, Sites and Neighborhoods of the Modern Movement (DoCoMoMo). All those international experts' gremials will be of major importance for an upcoming World Heritage of Kosovo, as described later. [4]

\subsection{World Heritage listed Monuments of Kosovo}

In 2016, more than a thousand properties the UNESCO World Heritage covers, one with strong relations to Kosovo. In 2004, Dečani Monastery was listed under the number 724. The state party of Serbia-Montenegro nominated it. By then, its location was in the "autonomous province of Kosovo and Metohija". In 2005, the Patriarchate of Peć Monastery, Graçanica Monastery and the Church of the Virgin of Ljeviša, enlarged this inscription in the World Heritage List as "Serbian Medieval Monuments of Kosovo and Metohija" (no.724bis). "The three churches reflect a high point in the development of the discrete Balkan Palaiologos Renaissance style, a fusion of the eastern orthodox Byzantine styles with western Romanesque influences, fostered by both the Serbian church and state at the height of its influence. [5] In 2006, the property showed up on the "Red List" of endangered heritage for: 1. Lack of legal status of the property; 2. Lack of legislative protection of the buffer zone; 3. Lack of implementation of the Management Plan and of active management; 4. Difficulties to monitor the property due to political instability, post conflict situations (visits under KFOR/UNMIK escort) and lack of guards and security; 5. Unsatisfactory state of conservation and maintenance of the property; [6]

As part of its independency process in 2008, Kosovo prepared on this particular case with the Law on Special Protective Zones (2008/03-L039). In 2015, the evaluation report of UNESCO still names civil unrest, legal framework, management systems/management plans and the unsatisfactory state of conservation and maintenance of the property as affecting factors of the property.

Here, the national monument protection institutions of the still young state seem to fail so far, which is extremely contra productive for Kosovo's recent attempts to join UNESCO. Even considered that also Butrint in Albania (no.570) and the bay of Kotor (no.125), both listed world heritage sites in the neighborhood, once had been on the list of endangered heritage, it is high times for the state of Kosovo and its monument protection institutions to act.
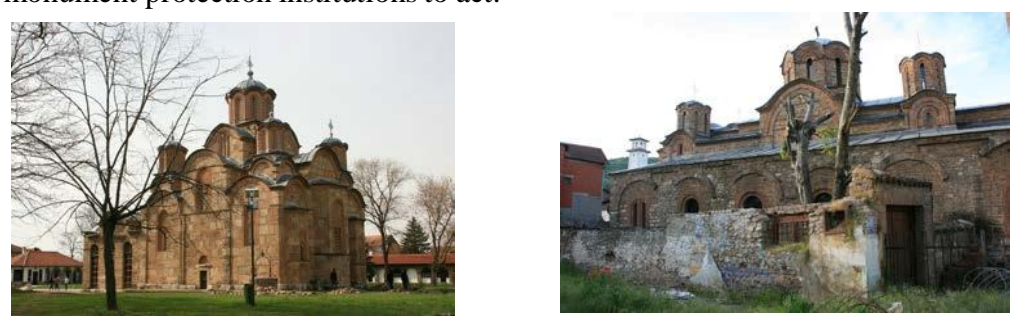

Fig. 3. Two of the four, world heritage listed monuments of Kosovo: Graçanica monastery church near Prishtina and Kisha e Shën Prendës in Prizren (author's photography in March 2014 and May 2015). 


\subsection{A Tentative List for Kosovo}

The WHC within UNESCO is not preparing the listing of the world heritage. Every national state has to do this himself for all natural-and cultural sites on his national territories. This list with the proposed national "candidates", we call The Tentative List. It is prepared either through the state authorities/institutions itself or by NGO's like ICOMOS or, recommended, in collaboration of both, as already quoted above. With his signature under the World Heritage Convention, each government of the state has agreed to prepare such a list and expressed its will to protect and maintain its selected properties according to the International Guidelines of UNESCO, but implemented by means of his own national law.

Since 1994, UNESCO is following a Global Strategy in its listing. It should represent all regions and cultures of the world equally and balanced. This global strategy favors countries like Kosovo for various reasons: it wants to encourage countries to join the World Heritage Convention; it tries to fill gaps within the World Heritage List; it tries to balance between cultural and natural heritage listed; it supports countries, not yet represented on the list, it its nominations and its tentative listing. [7] Besides those general scopes of the global strategy, new categories and certain focus points showed up recently. Let us explain this in detail on examples from the architectural heritage of Kosovo.

Probably the most named Kosovar candidate for the world heritage list is Prizren as most prominent Historic Town and Urban Area representing the Ottoman influence in central Balkans. The historian Olive Jens Schmitt summarizes this: Prizren raised to one of the most beautiful and important towns of the Ottomans and was deeply into the $19^{\text {th }}$ century the only real urban center on the territories of nowadays Kosovo. [8] Therefore, Prizren was already under the former Yugoslavian regime one of the few candidates for world heritage nomination, on equal height with nowadays world heritage listed properties like Dubrovnik (no.95bis) and Split (no.97). Additionally, the importance of the "Albanian League of Prizren" around 1877-78 for national autonomy/independency of the Albanian provinces of the Ottoman Empire [9]

Shukriu, $174 \mathrm{f}$.] and its built legacy still visible in Prizren are still strong arguments for a heritage inscription of Prizren besides its increasing threat through recent building activities quickly changing the historic city scape.
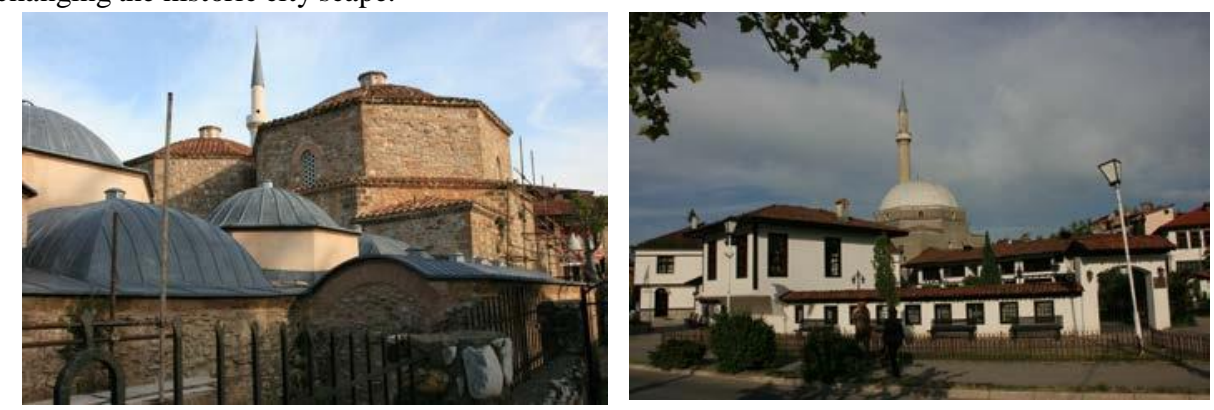

Fig. 4. Prizren, Hammam of Gazi Mehmed Pasha and Building Complex of the League of Prizren (author's photography in May 2015).

Since 1992 cultural landscapes is a well-accepted category within the world heritage and as combinations between cultural and natural heritage have priority for inscription. In the experts' understanding, (living) cultural landscapes are landscapes that gained their unique character through 


\section{Book of Proceedings \\ International Conference on Architecture and Spatial Planning}

the permanent interaction of humankind with nature. Kosovo has in its distinctive building type of the Albanian Kulla not only a good example for a cross-border nomination issue - the Kullat of the southwest of Kosovo extend into the north-east of Albania -, but probably also for a cultural landscape.
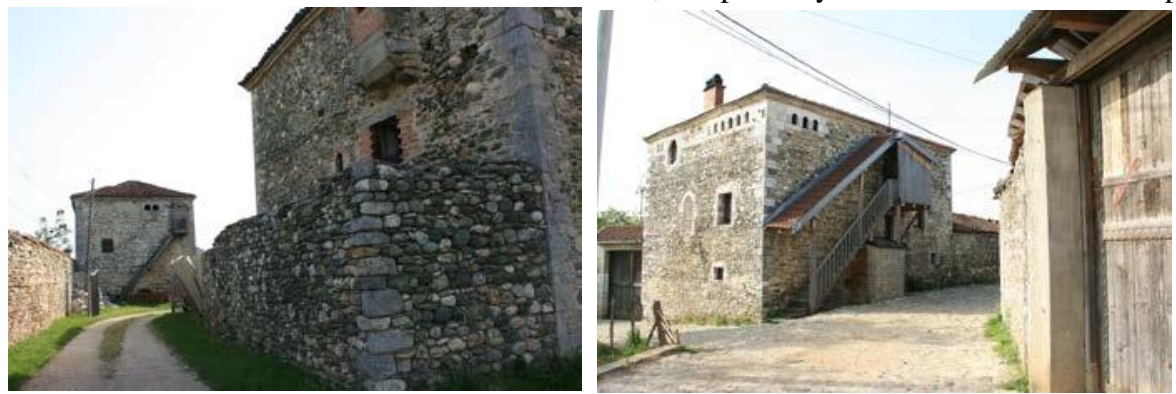

Fig. 5. Cultural Landscape of Dukgjin Kullat in Dranoc (author's photography in May 2015).

The Lex Dukagjin, the code of conduct for the society, helped forming this distinctive building type in context with the permanent blood feuds between its family clans. Therefore, a kulla is much more than a fortified tower house on the Dukagjin plains. It also formed the cultural landscape to clusters of kullat, with wall-enclosed generous grounds around the core building including a sophisticated distribution of official portal buildings and unofficial doorways, where the spatial and visual interaction between the men's room (oda), the top-gallery (dyshkellek) and the neighborhood within the village to be observed from there is the major formative factor.

Another kind of cultural landscape on the territories of Kosovo exists with the traditional trading routes through the country and the extent market places closely linked with them. The author hardly knows any other country, where the social interaction between the roads and bridges as most visible built remains, the trading guilds of the market places financing their erection and the extent market areas with their permanent sales as well as accommodation structures is still present as in Kosovo. The best-preserved space for illustration besides all war-caused destruction in the near past is Gjakova, but also Peja, Prizren and Vushtrii still give evidence. In Gjakova, nearly all features survived, from several bridges in its vicinity to the city structures caused by its market functions. Hans and konaks to accommodate the traders are still present within the cityscape. The market mosque and the clock tower (sahat kulla) to announce the opening times of the bazaar still form the city silhouette. Finally, a vast number of wooden market stands accompanies densely the different branches of the çashia. Although most of them had to be reconstructed after war destruction in 2000 and 2004, even some original structures remained. Altogether, the market town of Gjakova still gives authentic evidence for the social and economic interaction of many different people and peoples for matters of traditional trading which formed a quite specific cultural landscape of trading, if we consider the built remains along the routes additionally. 

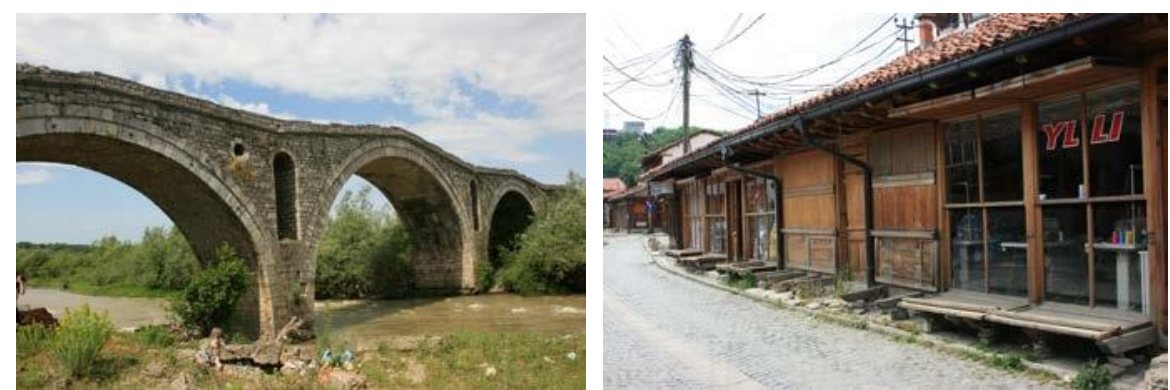

Fig. 6. Terzive (Tailors Guild) bridge on the way to and row of reconstructed wooden market stands within the market district of Gjakova (author's photography in March 2014 and May 2015).

Since 2008, there exists the ICOMOS Charter on Cultural Routes: The new concept ... shows the evolution of ideas with respect to the vision of cultural properties, as well as the growing importance of values related to their setting and territorial scale, and reveals the macrostructure of heritage on different levels. This concept introduces a model for a new ethics of conservation that considers these values as a common heritage that goes beyond national borders, It also helps to illustrate the contemporary social conception of cultural heritage values as a resource for sustainable social and economic development. ... Cultural Ro utes re p re s e $n t$ interactive, dynamic, and evolving processes of human intercultural links that reflect the rich diversity of the contributions of different peoples to cultural heritage. [10] With its so-called Saxonian mining towns (Novo Bërdo, Trepça and others), medieval silver mining centers of European dimension, which enabled the living together of mining and trading experts from different nations, religions and cultures, Kosovo provides a nice example for that new concept within the world heritage community.
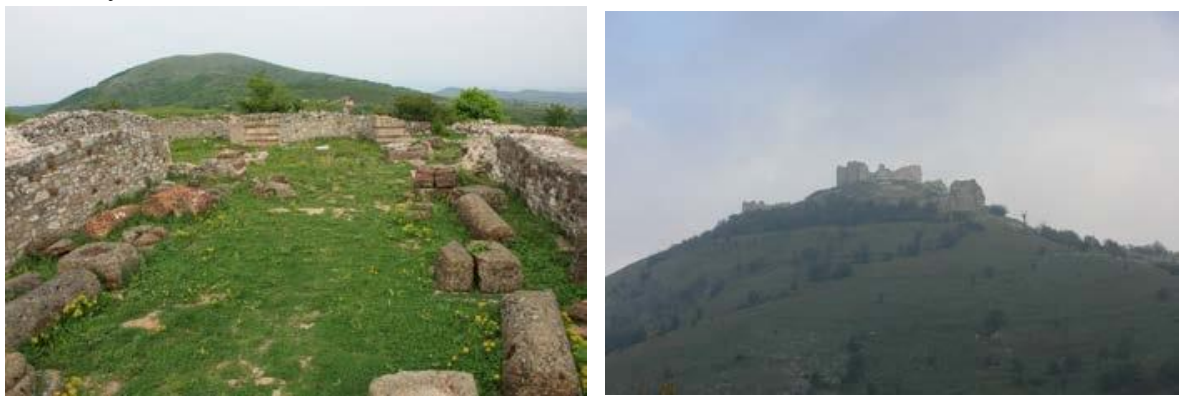

Fig. 7. Novo Bërdo: ruins of the Catholic Church and the fortress of this major medieval mining center of Balkans (author's photography in November 2014 and May 2015).

Certainly, the former Yugoslavian Modern Architecture would be the most ambitious serial heritage nomination and peace project between former war rivals on Balkans, if the former Yugoslavian republics and provinces, now the national states of Slovenia, Croatia, Serbia, Bosnia and Hercegovina, Montenegro, Macedonia and Kosovo would agree to cooperate. Besides, also from the technical standpoint, this cross-border and transnational nomination would be quite challenging. Hence, the UNESCO advisory body of DoCoMoMo (International Working Party for Document and Conservation of Buildings, Sites and Neighborhoods of the Modern Movement) would serve as 
Book of Proceedings

International Conference on Architecture and Spatial Planning

interesting platform for advice on this rather young architectural heritage field. Intensive exchange with Brazil, another focus point of modern architecture and important political factor within UNESCO, will be helpful, especially for issues of maintenance. We guarantee International attention and positive resonance on such a spectacular peace project in the field of cultural heritage.
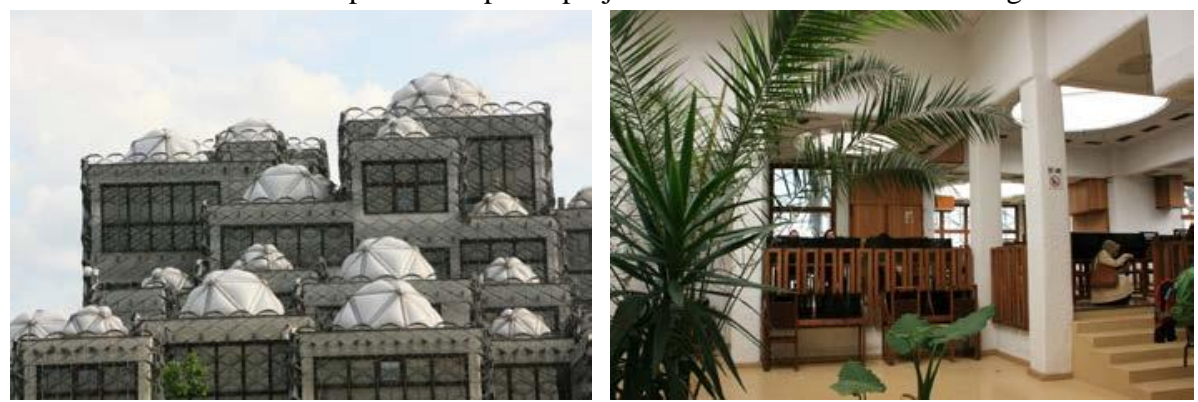

Fig. 8. Modern Architecture in Kosovo: National Library in Prishtina (author's photography in May 2015).

\section{Conclusions}

Adopted in 1972 by the UNESCO General Conference, the Convention Concerning the Protection of the World Cultural and Natural heritage represents an international effort that seeks to encourage the identification, protection and preservation of cultural and natural heritage considered to be of outstanding value to humanity. This international agreement is rooted in the recognition that protection of cultural and natural heritage of outstanding universal value (OUV) often remains incomplete at the national level, as countries lack the economic, scientific, and technological resources for preservation. [11] This 2015 quoting from Bertacchini and others exactly reflects the current the situation of Kosovo and therefore is the best argument pro Kosovo in UNESCO as quick as possible. With a serious analysis of recent developments within the "World Heritage Business", Kosovo hardly can fail to reclaim technical and financial support for its efforts to join the World Heritage Community. The circle around Meskell at Stanford University describes exactly the further impact of the once started process: At the international level, countries may benefit from World heritage by signaling the quality of their cultural and natural properties, attracting further resources from international cooperation in heritage protection or marketing their World Heritage sites as tourist destinations. [12] Both - the homework towards national monument protection not yet done at all and still undiscovered from otherwise omnipresent tourism - what is Kosovo still waiting for. Let us join UNESCO quickly, but professionally prepared!

\section{References}

1. en.wikipedia.org/UNESCO (29.9.2016) 
UNESCO World Heritage and Kosovo Towards a Tentative List for Kosovo

2. Meskell, Lynn et al., "Multilateralism and UNESCO World Heritage: decision-making, State Parties and political process", 423-440 in: International Journal of Heritage Studies,(2015), Vol.2, No. 5; 423f.

3. Internal Letter concerning Membership Admission Policy to all ICOMOS National Committee Presidents and Officers from Gustavo Araoz, President and John Hurd, Advisory Committee President (2013).

4. Deutsche, Österreichische, Schweizerische und Luxemburgische UNESCO-Kommission (Hg.), Welterbe-Manual. Handbuch zur Umsetzung der Welterbekonvention in Deutschland, Luxemburg, Österreich und der Schweiz, Bonn (2009, 2. Erw. Auflage), 51.

5. UNESCO World Heritage List No.724bis, Paris (2006), 141-148.

6. www.unesco.org/culture/World Heritage Centre/The List in Danger (29.9.2016).

7. Deutsche, Österreichische, Schweizerische und Luxemburgische UNESCO-Kommission (Hg.), Welterbe-Manual. Handbuch zur Umsetzung der Welterbekonvention in Deutschland, Luxemburg, Österreich und der Schweiz, Bonn (2009, 2. Erw. Auflage), $104 f$.

8. Schmitt, Oliver Jens, Kosovo. Kurze Geschichte einer zentralbalkanischen Landschaft, Wien (2008), 78f.

9. Shukriu, Edi, Kosova. A Monographic Survey, Prishtina (2013), $174 \mathrm{ff}$.

10. ICOMOS Deutschland, Luxemburg, Österreich, Schweiz (ed.), Monumenta I. International Principles and Guidelines of Conservation. Deutsche Übersetzungen, München (2012), $212 \mathrm{ff}$.

11. Bertacchini, Enrico, Liuzza, Claudia and Meskell, Lynn, Shifting the balance of power in the UNESCO World Heritage Committee: an empirical assessment, in: International Journal of Cultural Policy (June 2015), 1.

12. Bertacchini, Enrico, Liuzza, Claudia and Meskell, Lynn, Shifting the balance of power in the UNESCO World Heritage Committee: an empirical assessment, in: International Journal of Cultural Policy (June 2015), 6. 